\title{
Spectral and Mechanistic Investigation of Oxidative Decarboxylation of Phenylsulfinylacetic Acid by $\mathrm{Cr}$ (VI)
}

\author{
Perumal Subramaniam*, Natesan Thamil Selvi', and Soundarapandian Sugirtha Devi ${ }^{\star}$ \\ Research Department of Chemistry, Aditanar College of Arts and Science, Tiruchendur-628 216, India. \\ ${ }^{*}$ E-mail: subramaniam.perumal@gmail.com \\ ${ }^{\dagger}$ Department of Chemistry, Govindammal Aditanar College for Women, Tiruchendur-628 215, India \\ Department of Chemistry, Kamaraj College, Thoothukudi, India
}

(Received September 3, 2013; Accepted January 16, 2014)

\begin{abstract}
The oxidative decarboxylation of phenylsulfinylacetic acid (PSAA) by Cr(VI) in 20\% acetonitrile - $80 \%$ water (v/v) medium follows overall second order kinetics, first order each with respect to [PSAA] and $[\mathrm{Cr}(\mathrm{VI})]$ at constant $\left[\mathrm{H}^{+}\right]$and ionic strength. The reaction is acid catalysed, the order with respect to $\left[\mathrm{H}^{+}\right]$is unity and the active oxidizing species is found to be $\mathrm{HCrO}_{3}{ }^{+}$. The reaction mechanism involves the rate determining nucleophilic attack of sulfur atom of PSAA on chromium of $\mathrm{HCrO}_{3}{ }^{+}$forming a sulfonium ion intermediate. The intermediate then undergoes $\alpha, \beta$-cleavage leading to the liberation of $\mathrm{CO}_{2}$. The product of the reaction is found to be methyl phenyl sulfone. The operation of substituent effect shows that PSAA containing electron-releasing groups in the meta- and para-positions accelerate the reaction rate while electron withdrawing groups retard the rate. An excellent correlation is found to exist between $\log \mathrm{k}_{2}$ and Hammett $\sigma$ constants with a negative value of reaction constant. The $\rho$ value decreases with increase in temperature evidencing the high reactivity and low selectivity in the case of substituted PSAAs.
\end{abstract}

Key words: Phenylsulfinylacetic acid, Oxidative decarboxylation, Nucleophilic attack of sulfur, Substituent effect

\section{INTRODUCTION}

Despite the vast usage of $\mathrm{Cr}(\mathrm{VI})$ for analytical and synthetic purposes, ${ }^{1-3}$ it is well known for its carcinogenic and mutagenic activity. ${ }^{4-6}$ Though $\mathrm{Cr}(\mathrm{VI})$ is not directly responsible for DNA lesions, its tetrahedral conformation enables its active transport into the cell and generates highly reactive $\mathrm{Cr}(\mathrm{V}), \mathrm{Cr}(\mathrm{IV})$ and free radical intermediates by intracellular reduction capable of damaging DNA. ${ }^{7-9} \mathrm{Sev}-$ eral researchers reported the mechanism of DNA damage induced by $\mathrm{Cr}(\mathrm{VI})$, but the crucial facets of this mechanism remain essentially unknown. Hence, the mechanistic aspects of reduction of $\mathrm{Cr}(\mathrm{VI})$ are of biologically important.

Organic sulfur compounds are model biological reductants. Realizing the biological importance of the interaction between sulfur and chromium, $\mathrm{Cr}(\mathrm{VI})$ oxidation of many organic sulfur compounds have been examined. ${ }^{10-13}$ Depending on the substrate and experimental conditions, different mechanistic pathways have been envisaged for $\mathrm{Cr}(\mathrm{VI})$ oxidation reactions: one electron transfer mechanism involving the formation of a cation radical intermediate in the slow step; ${ }^{14,15}$ a two electron transfer mechanism leading to the formation of $\mathrm{Cr}(\mathrm{IV})$ intermediate, ${ }^{16}$ the mechanism involving the formation of a chromate thioester ${ }^{17}$ and its disproportionation in a slow step; ${ }^{18}$ the $\mathrm{S}_{\mathrm{N}} 2$ mechanism involving a nucleophilic attack of sulfur on chromium followed by ligand coupling between $\mathrm{S}$ and $\mathrm{O}^{15,19,20}$ the mechanism which follows Michalies-Menten kinetics with complex formation ${ }^{21}$ and slow decomposition of the complex. ${ }^{22}$ The present study of oxidative decarboxylation of phenylsulfinylacetic acid (PSAA) by $\mathrm{Cr}(\mathrm{VI})$ will be of particular interest owing to the application of PSAA in pharmaceutical preparations and in the synthesis of several organic compounds. ${ }^{23-29}$ The literature survey also reveals that there is no systematic report on the kinetic and mechanistic aspects on the oxidation of phenylsulfinylacetic acid except our recent report ${ }^{30}$ and hence the title investigation was undertaken to analyze the salient features of the reaction, the effect of substituents on the reaction rate and to arrive at a suitable mechanism.

\section{EXPERIMENTAL}

\section{Materials}

Phenylsulfinylacetic acid and several para- and metasubstituted phenylsulfinylacetic acids were prepared from the corresponding phenylmercaptoacetic acids by controlled oxidation using equimolar quantity of $\mathrm{H}_{2} \mathrm{O}_{2}{ }^{31}$ and recrystallised from suitable solvents. ${ }^{32}$ The recrystallised phe- 
nylsulfinylacetic acids were dried, melting points were determined and checked with the literature values. ${ }^{32}$ The purity was also ascertained by LC-MS for all the phenylsulfinylacetic acids. Then they were stored in the vacuum desiccator and used for the kinetic studies. Phenylmercaptoacetic acids required for the synthesis of PSAAs were synthesized by condensing chloroacetic acid $(4.7 \mathrm{~g}$ in $20 \mathrm{ml}$ of $20 \%$ sodium hydroxide) with appropriate thiophenol ( 0.05 mole) dissolved in $10 \mathrm{ml}$ of $20 \%$ sodium hydroxide at $120-130^{\circ} \mathrm{C}$ for five hours. The phenylmercaptoacetic acids formed were recrystallised from water and their melting points were verified with the literature values. ${ }^{32}$ Potassium dichromate (Merck), sodium perchlorate (Merck), perchloric acid (Merck) and all other reagents used were of AnalaR grade. Solvents, acetonitrile and water were purified by established procedures.

\section{Kinetic Measurements}

The reactions were carried out under pseudo first order conditions by maintaining [PSAA] $»[\mathrm{Cr}(\mathrm{VI})]$ in $20 \%$ acetonitrile $-80 \%$ water $(\mathrm{v} / \mathrm{v})$ medium. The progress of the reaction was followed, using Elico Double beam UV-vis Bio-spectrophotometer with an inbuilt thermostat, by monitoring the decrease in absorbance of $\mathrm{Cr}(\mathrm{VI})$ at the $\lambda_{\max }$ of $351 \mathrm{~nm}$ at definite time intervals.

The spectral changes at different time intervals during the course of the reaction are given in Fig. 1. The pseudo first order rate constant $\left(\mathrm{k}_{1}\right)$ for each kinetic run is evaluated from the slope of log OD vs time by the method of least squares. The second order rate constant $\left(\mathrm{k}_{2}\right)$ is calculated from the relation: $\mathrm{k}_{2}=\mathrm{k}_{1} /[\mathrm{PSAA}]$. The precision

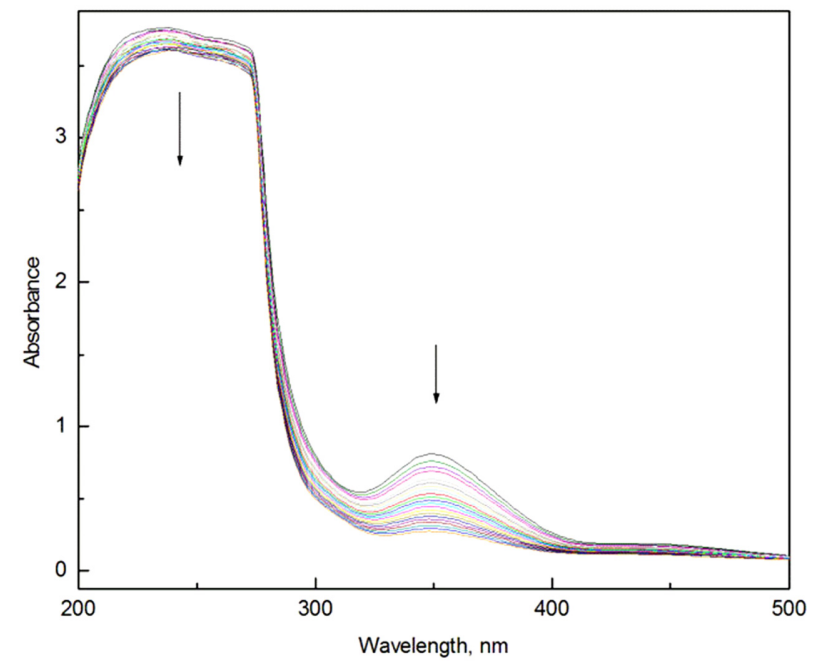

Figure 1. UV-visible spectra for the kinetic run, [PSAA] $=$ $5.0 \times 10^{-2} \mathrm{~mol} \mathrm{dm}^{-3},[\mathrm{Cr}(\mathrm{VI})]=3.0 \times 10^{-4} \mathrm{~mol} \mathrm{dm}^{-3},\left[\mathrm{H}^{+}\right]=0.75 \mathrm{~mol}$ $\mathrm{dm}^{-3}$. of the $\mathrm{k}$ values is given in terms of $95 \%$ confidence limits of the student's $t$ test.

\section{Stoichiometry and Product Analysis}

The stoichiometry of the reaction was determined by taking different ratios of $\mathrm{Cr}(\mathrm{VI})$ and PSAA concentrations under the condition [Cr(VI)]» [PSAA]. The estimation of unreacted $\mathrm{Cr}(\mathrm{VI})$ in the reaction mixture after completion of the reaction showed that two moles of $\mathrm{Cr}(\mathrm{VI})$ reacted with three moles of the substrate.

The reaction mixture in the stoichiometric condition was kept for 48 hours to ensure completion of the reaction. The solvent was then evaporated and extracted with ether. The ether layer was collected, dried over anhydrous sodium sulfate and the ether was removed by evaporation. IR and GC-MS analysis (Supplementary material: Figures S1 and S2) of the residue obtained from the ether extract confirm that methyl phenyl sulfone is the only product of the reaction. IR spectrum shows strong bands at $1148 \mathrm{~cm}^{-1}$ and $1290 \mathrm{~cm}^{-1}$ characteristic of symmetric and asymmetric stretching frequencies respectively for $>\mathrm{SO}_{2}$ group.

\section{RESULTS}

The UV-visible spectrum of $\mathrm{Cr}$ (III) ion shows two peaks at $410 \mathrm{~nm}$ and $580 \mathrm{~nm}$ which are attributed to the octahedral transitions, ${ }^{4} \mathrm{~A}_{2 \mathrm{~g}}(\mathrm{~F}) \rightarrow{ }^{4} \mathrm{~T}_{1 \mathrm{~g}}(\mathrm{~F})$ and ${ }^{4} \mathrm{~A}_{2 \mathrm{~g}}(\mathrm{~F}) \rightarrow{ }^{4} \mathrm{~T}_{2 \mathrm{~g}}(\mathrm{~F})$ of $\mathrm{Cr}$ (III) ${ }^{33-35}$ whereas that of the reaction mixture after completion of the reaction shows two peaks at $411 \mathrm{~nm}$ and $565 \mathrm{~nm}$ which confirms the existence of $\mathrm{Cr}(\mathrm{III})$ as the final product of $\mathrm{Cr}(\mathrm{VI})$. The observed blue shift in $\lambda_{\max }$ value at $580 \mathrm{~nm}$ for the product mixture clearly points out that the product $\mathrm{Cr}$ (III) exists not as a free state but in the form of complex ${ }^{36-39}$ with other species, probably with methyl phenyl sulfone.

The overlaid spectra of the reaction in the wavelength range 500-620 nm (Fig. 2) exhibit a delayed increase in OD which is consistent with the formation of $\mathrm{Cr}$ (III). The delayed increase in OD in the region 500-620 nm without any isobestic point clearly shows that there are two or more competing reactions involving $\mathrm{Cr}(\mathrm{III})$ in the final stage of the reaction. ${ }^{40}$

Under the experimental condition, [PSAA] » [Cr(VI)], the reaction exhibits first order dependence on $\mathrm{Cr}(\mathrm{VI})$ as evidenced by the linear log OD vs time plots even beyond $70 \%$ completion of the reaction. However, the calculated pseudo first order rate constants decrease with the increase in $\mathrm{Cr}(\mathrm{VI})$ concentrations (Table 1). The reason for this decrease in reaction rate may be due to the dimerization of $\mathrm{Cr}(\mathrm{VI})$ 


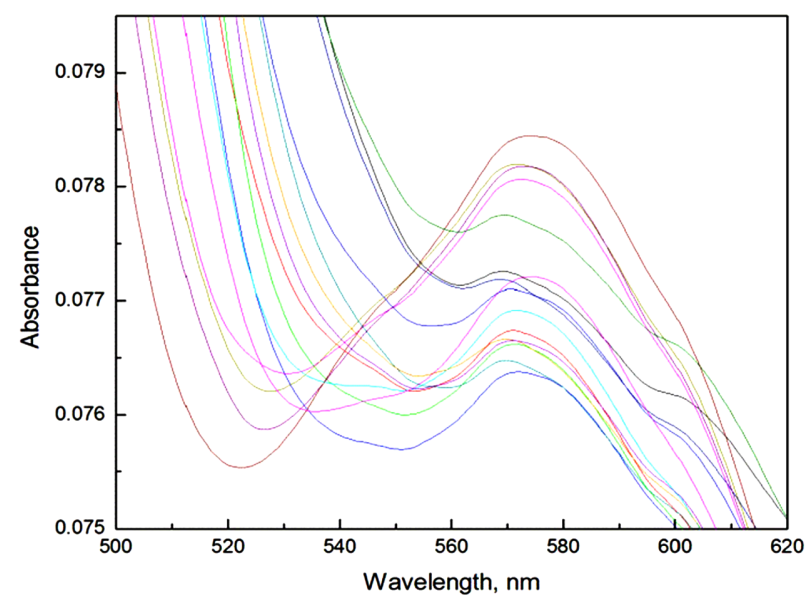

Figure 2. UV-visible spectra of the reaction mixture at different time intervals, $[\mathrm{PSAA}]=5.0 \times 10^{-2} \mathrm{~mol} \mathrm{dm}^{-3},[\mathrm{Cr}(\mathrm{VI})]=3.0 \times 10^{-4} \mathrm{~mol}$ $\mathrm{dm}^{-3},\left[\mathrm{H}^{+}\right]=0.75 \mathrm{~mol} \mathrm{dm}{ }^{-3}$.

Table 1. Pseudo first order and second order rate constants for the variation of reactants at $30^{\circ} \mathrm{C}$

\begin{tabular}{cccc}
\hline $\begin{array}{c}10^{2}[\mathrm{PSAA}] \\
\left.(\mathrm{mol} \mathrm{dm})^{-3}\right)\end{array}$ & $\begin{array}{c}10^{4}[\mathrm{Cr}(\mathrm{VI})] \\
\left(\mathrm{mol} \mathrm{dm}^{-3}\right)\end{array}$ & $\begin{array}{c}10^{4} \mathrm{k}_{1} \\
\left(\mathrm{~s}^{-1}\right)\end{array}$ & $\begin{array}{c}10^{2} \mathrm{k}_{2} \\
\left(\mathrm{~mol}^{-1} \mathrm{dm}^{3} \mathrm{~s}^{-1}\right)\end{array}$ \\
\hline 1.0 & 3.0 & $1.46 \pm 0.04$ & $1.46 \pm 0.04$ \\
2.0 & 3.0 & $2.94 \pm 0.08$ & $1.47 \pm 0.04$ \\
3.0 & 3.0 & $4.43 \pm 0.09$ & $1.48 \pm 0.03$ \\
5.0 & 3.0 & $7.42 \pm 0.12$ & $1.48 \pm 0.02$ \\
7.0 & 3.0 & $10.7 \pm 0.22$ & $1.53 \pm 0.03$ \\
9.0 & 3.0 & $13.6 \pm 0.20$ & $1.52 \pm 0.02$ \\
10 & 3.0 & $15.1 \pm 0.39$ & $1.51 \pm 0.04$ \\
5.0 & 1.0 & $15.8 \pm 0.29$ & $3.18 \pm 0.06$ \\
5.0 & 2.0 & $10.9 \pm 0.46$ & $2.19 \pm 0.09$ \\
5.0 & 4.0 & $6.57 \pm 0.32$ & $1.31 \pm 0.06$ \\
5.0 & 5.0 & $5.90 \pm 0.17$ & $1.18 \pm 0.03$ \\
5.0 & 6.0 & $4.29 \pm 0.33$ & $0.86 \pm 0.06$ \\
\hline
\end{tabular}

$\left[\mathrm{H}^{+}\right]=0.75 \mathrm{~mol} \mathrm{dm}^{-3} ; \mathrm{I}=0.80 \mathrm{~mol} \mathrm{dm}^{-3} ;$ Solvent $=20 \%$ acetonitrile $-80 \%$ water $(\mathrm{v} / \mathrm{v})$.

followed by decrease in concentration of active species at higher concentrations of $\mathrm{Cr}(\mathrm{VI}) .{ }^{41-44}$ Karunakaran et al. ${ }^{45}$ revealed that the increase in $[\mathrm{Cr}(\mathrm{VI})]$ may lead to some sort of weak association among the monomers resulting decrease in reactivity.

A plot of $\log \mathrm{k}_{1}$ vs $\log$ [PSAA] is linear with unit slope (slope $=1.02 \pm 0.01, r=0.999$ ) indicating that the order with respect to substrate is one. This is further confirmed by the constant second order rate constant values obtained at different initial concentrations of PSAA and the linear plot of $\mathrm{k}_{1}$ against [PSAA] $(\mathrm{r}=0.999)$ which passes through the origin.

The rate constants are found to increase appreciably with increase in the concentration of $\mathrm{HClO}_{4}$ (Supplemen- tary material: Table $\mathrm{S} 1)$. The reaction is first order with respect to hydrogen ion as evidenced from the unit slope of the plot of $\log \mathrm{k}_{1} \mathrm{vs} \log \left[\mathrm{H}^{+}\right]$(slope $=0.985 \pm 0.04, \mathrm{r}=$ 0.999 ) and constant value obtained by dividing pseudo first order rate constant by $\left[\mathrm{H}^{+}\right]$. The rate dependence on $\mathrm{H}^{+}$ establishes the involvement of protonated chromium species in the reaction. ${ }^{41}$ The effect of altering ionic strength on the rate of the reaction was investigated by adding sodium perchlorate and there is a slight increase in the rate with the increase in ionic strength of the medium (Supplementary material: Table S1). This could be attributed to the participation of a neutral molecule as one of the reactants in the rate determining step. ${ }^{46}$

The rate constant increases significantly with the increasing acetonitrile content of the medium (Supplementary material: Table S1) indicating a facile reactivity in the medium of low dielectric constant. The rate enhancement in low dielectric constant medium may be due to an increase in reduction potential of $\mathrm{Cr}(\mathrm{VI}) / \mathrm{Cr}(\mathrm{III})$ couple with increase in acetonitrile content in the medium. ${ }^{47,48}$ The plot of log $\mathrm{k}_{1}$ vs $1 /$ dielectric constant is linear $(\mathrm{r}=0.997)$ with a positive slope which indicates that one of the reactants involved in the rate controlling step is cationic in nature.

\section{SUBSTITUENT EFFECT}

As the study of influence of substituents on the rate of reaction often provides an insight into the nature of the transition state and mechanism, the rate constants for the oxidative decarboxylation of several meta- and para-substituted PSAAs are determined at three different temperatures, viz., $10{ }^{\circ} \mathrm{C}, 20^{\circ} \mathrm{C}$ and $30{ }^{\circ} \mathrm{C}$ and the second order rate constants are listed in Table 2.

The study of substituent effect reveals that electron releasing substituents accelerate the reaction rate while electron withdrawing substituents retard it. The second order rate constants of meta- and para-substituted PSAAs correlate excellently with Hammett substituent constants, $\sigma$ with negative slope values (Fig. 3).

The negative reaction constants, $\rho$ support the generation of electron deficient sulfur center in the transition state. The second order rate constant values obtained at three different temperatures for the meta- and para-substituted PSAAs, are employed to get thermodynamic parameters, $\Delta^{*} \mathrm{H}$ and $\Delta \mathrm{S}$ from the slope and intercept values of Eyring's plots and are enumerated in Table 2. The data collected in Table 2 shows that the change in substituents in the phenyl group of PSAA has no effect on the enthalpy of activation, $\left(\Delta^{*} \mathrm{H}\right)$. 
Table 2. Second order rate constants, enthalpy and entropy of activation for the oxidative decarboxylation of $\mathrm{XC}_{6} \mathrm{H}_{4} \mathrm{SOCH}_{2} \mathrm{COOH}$

\begin{tabular}{|c|c|c|c|c|c|}
\hline \multirow{2}{*}{$X$} & \multicolumn{3}{|c|}{$10^{3} \mathrm{k}_{2}\left(\mathrm{~mol}^{-1} \mathrm{dm}^{3} \mathrm{~s}^{-1}\right)$} & \multirow{2}{*}{$\begin{array}{c}\Delta^{*} \mathrm{H} \\
\left(\mathrm{kJ} \mathrm{mol}^{-1}\right)\end{array}$} & \multirow{2}{*}{$\begin{array}{c}-\Delta^{*} \mathrm{~S} \\
\left(\mathrm{JK}^{-1} \mathrm{~mol}^{-1}\right)\end{array}$} \\
\hline & $10^{\circ} \mathrm{C}$ & $20^{\circ} \mathrm{C}$ & $30^{\circ} \mathrm{C}$ & & \\
\hline $\mathrm{m}-\mathrm{Br}$ & $1.18 \pm 0.08$ & $4.86 \pm 0.19$ & $9.86 \pm 0.46$ & $73.55 \pm 3.7$ & $39.99 \pm 13.4$ \\
\hline $\mathrm{m}-\mathrm{Cl}$ & $1.25 \pm 0.05$ & $4.21 \pm 0.17$ & $10.4 \pm 0.37$ & $73.57 \pm 2.8$ & $40.02 \pm 10.1$ \\
\hline $\mathrm{m}-\mathrm{F}$ & $1.26 \pm 0.07$ & $5.07 \pm 0.15$ & $12.3 \pm 0.39$ & $79.08 \pm 2.8$ & $20.21 \pm 10.2$ \\
\hline $\mathrm{p}-\mathrm{Cl}$ & $1.77 \pm 0.08$ & $6.29 \pm 0.27$ & $17.3 \pm 0.79$ & $78.83 \pm 3.2$ & $18.57 \pm 11.6$ \\
\hline $\mathrm{p}-\mathrm{Br}$ & $2.06 \pm 0.10$ & $6.94 \pm 0.25$ & $18.1 \pm 0.66$ & $75.28 \pm 2.9$ & $29.88 \pm 10.5$ \\
\hline $\mathrm{p}-\mathrm{F}$ & $3.30 \pm 0.08$ & $9.24 \pm 0.29$ & $23.9 \pm 0.66$ & $68.47 \pm 1.9$ & $50.23 \pm 7.21$ \\
\hline $\mathrm{H}$ & $3.50 \pm 0.16$ & $11.4 \pm 0.42$ & $31.1 \pm 0.64$ & $75.58 \pm 2.5$ & $24.49 \pm 8.94$ \\
\hline $\mathrm{m}-\mathrm{CH}_{3}$ & $5.19 \pm 0.19$ & $15.2 \pm 0.45$ & $41.7 \pm 2.19$ & $72.01 \pm 2.8$ & $33.98 \pm 10.3$ \\
\hline $\mathrm{p}-\mathrm{CH}_{3}$ & $7.18 \pm 0.38$ & $23.7 \pm 0.90$ & $53.7 \pm 3.91$ & $69.55 \pm 3.9$ & $39.56 \pm 14.2$ \\
\hline p-t-bu & $7.99 \pm 0.31$ & $26.3 \pm 2.31$ & $59.6 \pm 2.55$ & $69.39 \pm 4.0$ & $39.19 \pm 14.7$ \\
\hline $\mathrm{p}-\mathrm{OC}_{2} \mathrm{H}_{5}$ & $8.22 \pm 0.26$ & $24.9 \pm 1.27$ & $58.3 \pm 1.05$ & $67.63 \pm 2.4$ & $45.34 \pm 8.68$ \\
\hline $\mathrm{p}-\mathrm{OCH}_{3}$ & $10.5 \pm 0.49$ & $30.7 \pm 2.36$ & $68.4 \pm 2.74$ & $64.51 \pm 3.9$ & $54.31 \pm 14.2$ \\
\hline$\rho$ & $-1.42 \pm 0.08$ & $-1.27 \pm 0.12$ & $-1.25 \pm 0.08$ & & \\
\hline $\mathrm{r}$ & 0.997 & 0.990 & 0.996 & & \\
\hline
\end{tabular}

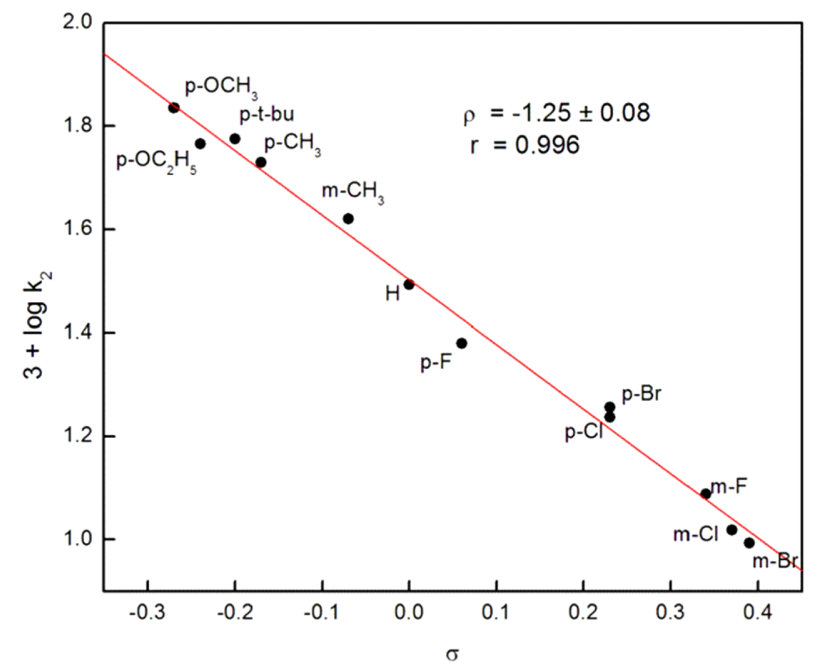

Figure 3. Hammett plot for the reactions of substituted PSAAs with $\mathrm{Cr}(\mathrm{VI})$ at $30^{\circ} \mathrm{C},\left[\mathrm{XC}_{6} \mathrm{H}_{4} \mathrm{SOCH}_{2} \mathrm{COOH}\right]=3.0 \times 10^{-2} \mathrm{~mol} \mathrm{dm}^{-3}$, $[\mathrm{Cr}(\mathrm{VI})]=3.0 \times 10^{-4} \mathrm{~mol} \mathrm{dm}^{-3} ;\left[\mathrm{H}^{+}\right]=0.75 \mathrm{~mol} \mathrm{dm}^{-3} ; \mathrm{I}=0.8 \mathrm{~mol} \mathrm{dm}^{-3}$; Solvent: $40 \% \mathrm{CH}_{3} \mathrm{CN}-60 \% \mathrm{H}_{2} \mathrm{O}(\mathrm{v} / \mathrm{v})$.

A linear relationship between the enthalpies and entropies called the isokinetic relationship, $\Delta^{*} \mathrm{H}=\Delta^{*} \mathrm{H}_{0}+\beta^{*} \mathrm{~S}$, where $\beta$ is the isokinetic temperature, is valid only if the Petersen's ${ }^{49}$ error criteria is satisfied i.e., for a valid relationship between $\Delta^{*} \mathrm{H}$ and $\Delta^{*} \mathrm{~S}$, the range of observed $\Delta^{*} \mathrm{H}$ $\left(\Delta^{*} \mathrm{H}\right)$ must exceed $2 \delta$ ( $\delta$ is the maximum possible error). In the present series of reactions, although Petersen's error criteria is satisfied the plot of $\Delta^{*} \mathrm{H}$ vs $\Delta^{*} \mathrm{~S}$ gives only a fair correlation $(r=0.934)$. Hence, Exner's ${ }^{50}$ plot of $\log \mathrm{k}_{2}\left(30^{\circ} \mathrm{C}\right)$ against $\log \mathrm{k}_{2}\left(10^{\circ} \mathrm{C}\right)$ is made which gives an excellent correlation $(\mathrm{r}=0.994)$. The isokinetic temperature calculated from Exner's plot is $192.4 \mathrm{~K}$, which is below the experimental temperature.

\section{DISCUSSION}

The data in Table 2 demonstrate that the reactivity of PSAA is altered significantly by changing the substituents in the meta- and para-positions of the phenyl ring of PSAA. Also within a given set of substituted PSAAs appreciable increase in reactivity is noted with increase in temperature i.e., the $\rho$ value decreases with increase in temperature. The high reactivity ( $\mathrm{k}_{2}$ value) and low selectivity ( $\rho$ value) observed at high temperatures in the case of substituted PSAAs prompted to the conclusion that the reactivityselectivity principle (RSP) is in operation in this system. Hence, an attempt has been made to analyse the data by applying the method formulated by Exner ${ }^{51}$ to verify the operation of RSP. Accordingly the rate data reported in Table 2 is subjected to mathematical treatment using the following equations.

$$
\begin{aligned}
& \log k_{F i}=a+b \log k_{S i}+\varepsilon_{i} \\
& \Delta=\left(\sum_{i} \log k_{F i}-\sum_{i} \log k_{S i}\right) / N
\end{aligned}
$$

where $\mathrm{k}_{\mathrm{Fi}}$ and $\mathrm{k}_{\mathrm{Si}}$ are the second order rate constants for the fast and slow reactions i.e., at high and low temperatures respectively. $\varepsilon_{\mathrm{i}}$ is the error of the $\log \mathrm{k}_{\mathrm{Fi}}$ versus $\log \mathrm{k}_{\mathrm{Si}}$ correlation, $\mathrm{N}$ is the total number of data points and $\Delta$ is the mean difference. 


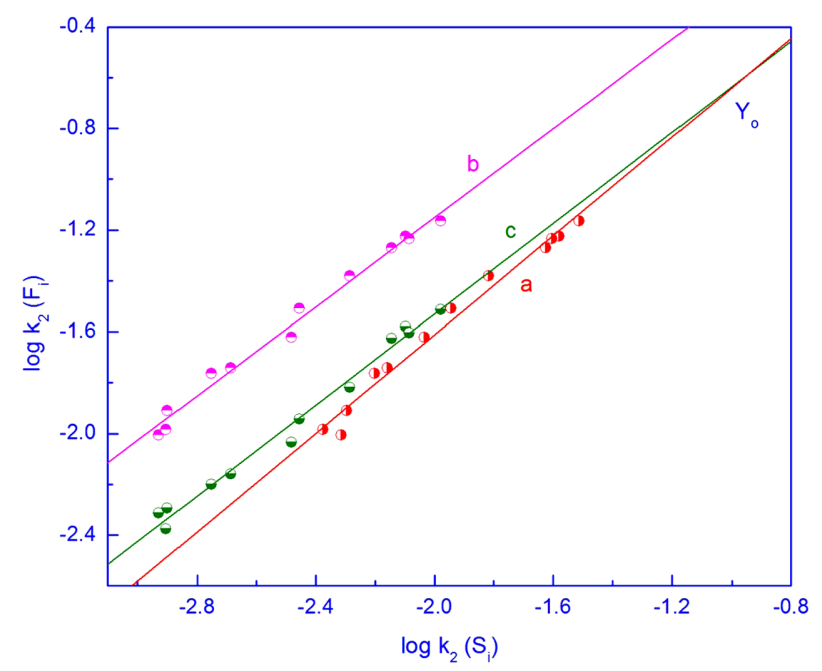

Figure 4. Correlation between $\log \mathrm{k}_{\mathrm{Fi}}$ and $\log \mathrm{k}_{\mathrm{Si}}$ (a) $30{ }^{\circ} \mathrm{C}$ vs $20{ }^{\circ} \mathrm{C}$; (b) $30{ }^{\circ} \mathrm{C}$ vs $10{ }^{\circ} \mathrm{C}$; (c) $20^{\circ} \mathrm{C}$ vs $10{ }^{\circ} \mathrm{C}$.

Table 3. Results of correlation between $\log \mathrm{k}_{\mathrm{Fi}}$ versus $\log \mathrm{k}_{\mathrm{si}}$

\begin{tabular}{cccc}
\hline & $30{ }^{\circ} \mathrm{C}$ and $20^{\circ} \mathrm{C}$ & $30{ }^{\circ} \mathrm{C}$ and $10{ }^{\circ} \mathrm{C}$ & $20^{\circ} \mathrm{C}$ and $10{ }^{\circ} \mathrm{C}$ \\
\hline $\mathrm{b}$ & $0.971 \pm 0.04$ & $0.877 \pm 0.03$ & $0.894 \pm 0.03$ \\
$\Delta$ & 0.388 & 0.908 & 0.519 \\
$\mathrm{r}$ & 0.991 & 0.994 & 0.993 \\
\hline
\end{tabular}

In the present system, among the three possible combinations of one fast reaction and one slow reaction at three different temperatures with a series of PSAAs, two combinations viz., $30^{\circ} \mathrm{C}$ vs $20^{\circ} \mathrm{C}$ and $20^{\circ} \mathrm{C}$ vs $10^{\circ} \mathrm{C}$ meet at a point, $\mathrm{Y}_{0}$, and produce a magic point. The linear correlations obtained using equation (1) is depicted in Fig. 4.

The values of $\mathrm{b}$ obtained from equation (1) and $\Delta$ calculated from equation (2), for all the three possible combinations of one fast and one slow reaction, are summarized in Table 3. The existence of magic point which is situated on the side of higher reactivity and the observed values of $\mathrm{b}$ which are less than unity and not too small values of $\Delta$ are indication for the operation of a strong $\mathrm{RSP}^{51}$ in the present system. Such type of evidences have been taken for a valid RSP in many cases of salen catalysed oxidation of organic sulfides and sulfoxides by Chellamani et al. ${ }^{52-55}$

The active species involved in the reaction may be $\mathrm{Cr}(\mathrm{VI})$ itself or $\mathrm{Cr}(\mathrm{V})$ formed as a result of one electron transfer or $\mathrm{Cr}(\mathrm{IV})$ as a result of two electron transfer. The absence of absorption at $750 \mathrm{~nm}$, where $\mathrm{Cr}(\mathrm{V})$ is the only absorbing species ${ }^{56}$ rules out $\mathrm{Cr}(\mathrm{V})$ as the active species. The insensitivity of rate on added radical scavenger, acrylamide, and $\mathrm{Mn}^{2+}$ ions, scavenger for $\mathrm{Cr}(\mathrm{IV})$ rule out the involvement of $\mathrm{Cr}(\mathrm{V})$ and $\mathrm{Cr}(\mathrm{IV})$ respectively as active species. Hence, the active species in this reaction is assumed to be $\mathrm{Cr}(\mathrm{VI})$ itself which exists in aqueous acidic solution in a variety of forms such as $\mathrm{H}_{2} \mathrm{CrO}_{4}, \mathrm{HCrO}_{4}{ }^{-}$and $\mathrm{HCrO}_{3}{ }^{+}$ depending on the $\mathrm{pH}$ of the medium. At low concentrations of $\mathrm{H}^{+}$it was observed that $\mathrm{Cr}(\mathrm{VI})$ exists predominantly as the monomer, $\mathrm{HCrO}_{4}{ }^{-57,58}$ and at higher concentrations of $\mathrm{H}^{+}$it mainly exists as $\mathrm{HCrO}_{3}{ }^{+} \cdot{ }^{+4,19,59}$ Under the present experimental condition of $0.75 \mathrm{~mol} \mathrm{dm}^{-3}\left[\mathrm{H}^{+}\right], \mathrm{HCrO}_{3}{ }^{+}$is assumed to be the effective oxidizing species. The positive nature of the oxidizing species is also evident from the positive slope obtained from the dielectric constant studies. The first order dependence of the reaction rate on $\mathrm{H}^{+}$ gives further evidence for the protonated species, $\mathrm{HCrO}_{3}{ }^{+}$.

As the concentration of $\mathrm{Cr}(\mathrm{VI})$ is increased, progressively a smaller portion of the $\mathrm{HCrO}_{3}{ }^{+}$is transformed into $\mathrm{Cr}_{2} \mathrm{O}_{7}{ }^{2-}$ and protonated forms according to the equilibrium (3) and these dimeric forms are the predominant spe-

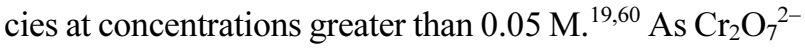
and its protonated forms are poor electrophiles as compared to $\mathrm{HCrO}_{3}{ }^{+}$, this may be the reason for the decrease in rate constants with increasing $\mathrm{Cr}(\mathrm{VI})$ concentration.

$$
2 \mathrm{HCr}^{+} \mathrm{O}_{3}+\mathrm{H}_{2} \mathrm{O} \rightleftarrows \mathrm{Cr}_{2} \mathrm{O}_{7}^{2-}+4 \mathrm{H}^{+}
$$

The spectral change observed in the region of $\lambda_{\max }$ between 230 and $270 \mathrm{~nm}$ becomes more important for the mechanistic study of $\mathrm{Cr}(\mathrm{VI})$ and sulfur compounds as it gives direct evidence for the existence of bond between chromium and sulfur. ${ }^{61-63}$ The time-dependent UV-visible spectrum of the reaction (Fig. 1) shows two equally intense absorption bands at $237 \mathrm{~nm}$ and $262 \mathrm{~nm}$ which have decreasing intensity with time. The decrease in intensity of absorption in this region with time may be due to the weakening of $\mathrm{Cr}(\mathrm{VI})-\mathrm{S}$ bond as a result of decrease in concentration of PSAA and $\mathrm{Cr}(\mathrm{VI})$. The change in the absorption spectra of $\mathrm{Cr}(\mathrm{VI})$ with PSAA, the significant hyperchromic shift and the widening of the peak in the region 200-300 nm for the reaction mixture (Fig. 5) confirm the existence of the $\mathrm{Cr}(\mathrm{VI})$-PSAA complex (I) having direct S-Cr bond. ${ }^{61}$

On the basis of the above observed experimental results, the nucleophilic attack of sulfur atom of PSAA on the chromium atom of the oxidizing species, $\mathrm{HCrO}_{3}{ }^{+}$is proposed as the initial step of the mechanism (Scheme 1). As a result of nucleophilic attack of PSAA, a positive charge is developed on the sulfur center in the transition state (I).

The observed substituent effects and negative values of $\rho$ afford positive evidence for the formation of PSAA$\mathrm{Cr}(\mathrm{VI})$ intermediate, (I) and also support its formation as a slow rate determining step. From the above mechanism it 


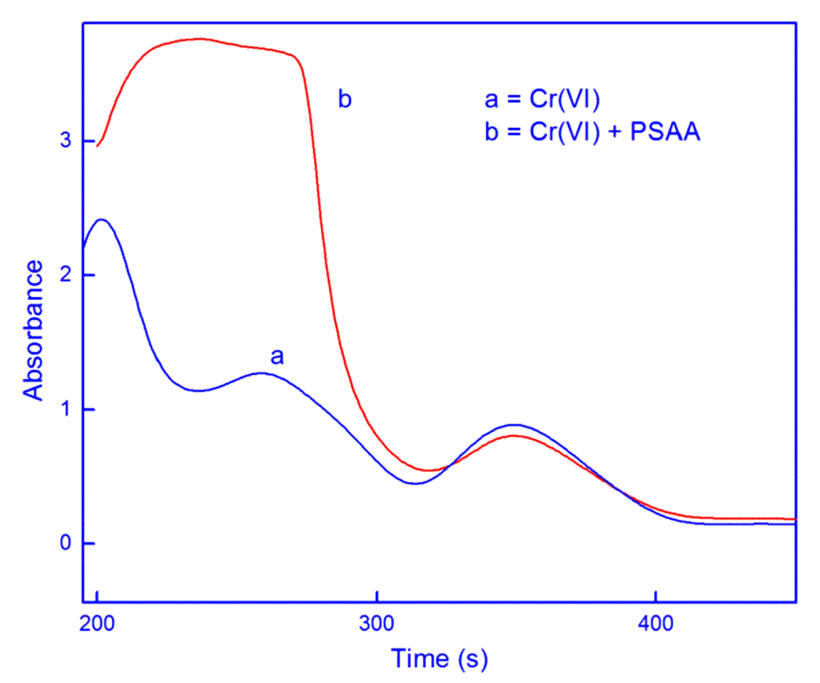

Figure 5. Absorption spectra of $\mathrm{Cr}(\mathrm{VI})$ and reaction mixture, $[\mathrm{Cr}(\mathrm{VI})]=3 \times 10^{-4} \mathrm{~mol} \mathrm{dm}^{-3} ;[\mathrm{PSAA}]=5 \times 10^{-2} \mathrm{~mol} \mathrm{dm}^{-3} ;\left[\mathrm{H}^{+}\right]$ $=0.75 \mathrm{~mol} \mathrm{dm}^{-3}$.

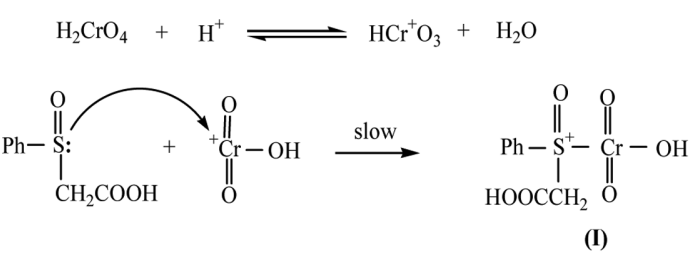<smiles>O=C(O)OC(=O)CO</smiles><smiles>CCCCCCCCCCCC(=O)O</smiles><smiles>CS1(=O)(c2ccccc2)O[Ge]2(O)O[C@@]21O</smiles>

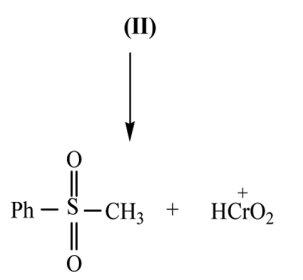

Scheme 1. Oxidative decarboxylation of PSAA by $\mathrm{Cr}(\mathrm{VI})$.

is clear that electron releasing substituents in PSAA stabilize the sulfonium ion intermediate, (I) formed in the rate determining step through resonance interaction besides facilitating the nucelophilic attack of PSAA on chromium atom (Eqn. 5). Thus electron releasing groups attached to the phenyl group of PSAA facilitate the formation of intermediate (I) by enhancing the nucleophilic ability of PSAA and thereby the reaction rate. On the contrary, the reverse effects are operating in eqn. (5) by electron withdrawing substituents. Thus one could expect a change in rate from acceleration to retardation, upon changing the substituents from electron releasing to electron withdrawing.

Such type of $\mathrm{S}_{\mathrm{N}} 2$ nucleophilic attack is evidenced from the insignificant change in reaction rate in the presence of varying concentration of radical scavenger, acrylamide from $0.5 \times 10^{-2} \mathrm{~mol} \mathrm{dm}^{-3}$ to $5.0 \times 10^{-2} \mathrm{~mol} \mathrm{dm}^{-3}$ which also eliminates the possibility of single electron transfer mechanism leading to the formation of organic free radicals. The $\rho$ values observed by altering the electronic nature of substituents in PSAA in this reaction (Table 2) also well agree with the $\rho$ values observed in other $\mathrm{S}_{\mathrm{N}} 2$ type reactions involving organic sulfur compounds, ${ }^{64-66}$ thus favouring the proposed mechanism. Generally, single electron transfer processes are characterized by low $\rho$ values. ${ }^{67,68}$ Further, the successful application of reactivity-selectivity principle, which cannot be applied for one electron transfer reactions, strongly supports the $S_{N} 2$ type nucleophilic attack leading to the formation of PSAA-Cr(VI) complex. The existence of PSAA-Cr(VI) complex in the rate determining step but not complete transfer of two electrons from PSAA to $\mathrm{Cr}(\mathrm{VI})$ leading to the formation of $\mathrm{Cr}(\mathrm{IV})$ in a slow step is also inferred from the absence of any significant change in reaction rate with the addition of $\mathrm{Mn}^{2+}\left(1.0 \times 10^{-3} \mathrm{~mol} \mathrm{dm}^{-3}\right.$ to $50 \times 10^{-3} \mathrm{~mol} \mathrm{dm}^{-3}$ ) to the reaction mixture.

The association of reactant molecules in the rate determining step to form a considerably rigid transition state (intermediate I) with the decrease in degrees of freedom of the molecules is also suggested on the basis of the observed negative entropy of activation values (Table 2). Another observation noted is that, $\mathrm{p}-\mathrm{Cl}$ PSAA has the lowest negative entropy of activation $\left(-18.57 \mathrm{JK}^{-1} \mathrm{~mol}^{-1}\right)$ in the present series of reactants while $\mathrm{p}-\mathrm{OCH}_{3}$ PSAA has the highest value $\left(-54.31 \mathrm{JK}^{-1} \mathrm{~mol}^{-1}\right)$. It is also noted that the calculated entropy of activation for the reaction of PSAA at $20 \% \mathrm{CH}_{3} \mathrm{CN}$ $-80 \% \mathrm{H}_{2} \mathrm{O}$ mixture is $-19.28 \mathrm{JK}^{-1} \mathrm{~mol}^{-1}$ and that at $40 \%$ $\mathrm{CH}_{3} \mathrm{CN}-60 \% \mathrm{H}_{2} \mathrm{O}$ is $-24.49 \mathrm{JK}^{-1} \mathrm{~mol}^{-1}$.

The development of positive charge on the sulfur atom of PSAA in the PSAA-Cr(VI) complex (I) facilitates the formation of intermediate (II) by ligand coupling between $\mathrm{O}$ and $\mathrm{S}^{15,19,42}$ with the simultaneous $\mathrm{C}_{\alpha}-\mathrm{C}_{\beta}$ bond cleavage ${ }^{69}$ leading to the elimination of $\mathrm{CO}_{2}$ in a fast step. The liberation of $\mathrm{CO}_{2}$ during the course of the reaction is confirmed using the method reported by Crossno et al. ${ }^{70}$ The presence of phenyl group attached to the positively charged sulfur center in (I) further accelerates the formation of intermediate (II). Subsequently, the intermediate (II) undergoes a redox decomposition with a two electron transfer in a fast step that leads to the formation of products, methyl phenyl sulfone and Cr(IV) (Scheme 1). The excellent plots of Hammett correlation obtained between second order rate constants and $\sigma$ values along with the isokinetic relationship and successful operation of reactivity-selectivity principle unam- 
biguously prove that all the substituted PSAAs follow the same mechanism in the present reaction series.

The Cr(IV) species formed in this step undergoes disproportionation in the subsequent fast steps leading to the final product $\mathrm{Cr}(\mathrm{III})$. Such a sequence of reactions in $\mathrm{Cr}(\mathrm{VI})$ oxidations is well known and different ways of disproportionation have been proposed by different researchers. Westheimer ${ }^{60}$ proposed the following type of disproportionation reaction:

$$
\begin{aligned}
& \mathrm{Cr}(\mathrm{IV})+\mathrm{Cr}(\mathrm{VI}) \rightarrow 2 \mathrm{Cr}(\mathrm{V}) \\
& \mathrm{Cr}(\mathrm{V})+\mathrm{PSAA} \rightarrow \mathrm{MeSO}_{2} \mathrm{Ph}+\mathrm{Cr}(\mathrm{III})
\end{aligned}
$$

Though the oxidation of $\mathrm{Cr}(\mathrm{IV})$ by $\mathrm{Cr}(\mathrm{VI})$ is thermodynamically unfavourable, ${ }^{71}$ the transient $\mathrm{Cr}(\mathrm{IV})$-aqua species reacts with $\mathrm{Cr}(\mathrm{VI})$ very fast. ${ }^{72}$ In strongly acidic media, generally $\mathrm{Cr}(\mathrm{IV})$ remains as aqua complexes ${ }^{73-76}$ and hence, in the present study the disproportionation of $\mathrm{Cr}$ (IV) follows Westheimer's mechanism (Eqs. 7 and 8).

\section{CONCLUSION}

The active oxidizing species of $\mathrm{Cr}(\mathrm{VI})$ in the oxidative decarboxylation of PSAA is found to be $\mathrm{HCrO}_{3}{ }^{+}$. The proposed mechanism involving rate determining nucleophilic attack of sulfur on chromium followed by fast ligand coupling and decarboxylation are in conformity with the product analysis and kinetic studies. An excellent Hammett correlation is obtained for the meta- and para-substituted phenylsulfinylacetic acids. The existence of isokinetic relationship and the operation of structure-reactivity principle confirm that all the meta- and para-substituted phenylsulfinylacetic acids follow the same mechanism.

Acknowledgments. The publication cost of this paper was supported by the Korean Chemical Society.

\section{REFERENCES}

1. Cainelli, G; Cardillo, G. Chromium Oxidations in Organic Chemistry; Springer: Berlin, 1984.

2. Li, M.; Johnson, M. E. Synth. Commun. 1995, 25, 533.

3. Korotin, M. A.; Anisimov, V. I.; Khomskii, D. I.; Sawatzky, G. A. Phys. Rev. Lett. 1998, 80, 4305.

4. Urbano, A. M.; Ferreira, L. M. R.; Alpoim, M. C. Curr. Drug Metab. 2012, 13, 284.

5. Sobol, Z.; Schiestl, R. H. Environ. Mol. Mutagen. 2012, 53, 94.

6. Wise, S. S.; Holmes, A. L.; Wise, J. P. Sr. Rev. Environ. Health 2008, 23, 39.

7. Nickens, K. P.; Patierno, S. R.; Ceryak, S. Chem-Biol. Interact. 2010, 188, 276.
8. Little, L. G.; Sugden, K. D. Metal Complex-DNA Interactions 2009, 463.

9. Macfie, A.; Hagan, E.; Zhitkovich, A. Chem. Res. Toxicol. 2010, 23, 341.

10. Gurumurthy, R.; Anandabaskaran, T.; Sathiyanarayanan, K. Oxid. Commun. 1998, 21, 222.

11. Krishnasamy, K.; Venkateswaran, V.; Shanmugam, M.; Dharmaraja, J. J. Sulfur Chem. 2007, 28, 365.

12. Karunakaran, C.; Chidambaranathan, V. Oxid. Commun. 1998, 21, 381.

13. Levina, A.; Zhang, L.; Lay, P. A. J. Am. Chem. Soc. 2010 , $132,8720$.

14. Srinivasan, C.; Chellamani, A.; Rajagopal, S. J. Org. Chem. 1985, 50, 1201.

15. Ganesan, T. K.; Rajagopal, S.; Bharathy, J. B. Tetrahedron 2000, 56, 5885.

16. Panigrahi, G. P.; Mahapatro, D. D. Int. J. Chem. Kinet. 1981, 13, 85.

17. Olatunji, M. A.; Ayoko, G. A. Polyhedron 1988, 7, 11.

18. Dilsha, K. M.; Kothari, S. Prog. React. Kinet. Mech. 2007, 32,119 .

19. Pitchumani, K.; Subramanian, V.; Jegatheesan, P. P.; Srinivasan, C. Proc. Indian Acad. Sci. (Chem. Sci.) 1992, 104, 67.

20. Sankararaj, B.; Rajagopal, S.; Pitchumani, K. Indian J. Chem. 1995, 34A, 440.

21. Pandey, D.; Kothari, S. Prog. React. Kinet. Mech. 2009, 34, 199.

22. Karunakaran, C.; Venkataramanan, R.; Kamalam, R. Monatsh Chem. 1999, 130, 1461.

23. Sumangala, V.; Boja Poojary; Chidananda, N.; Arulmoli, T.; Shalini Shenoy J. Chem. Pharm. Res. 2012, 4, 1661.

24. Gogan, N. J.; Newlands, M. J.; Tan, B.-Y. Can. J. Chem. 1972, 50, 3203.

25. Janczewski, M.; Najda, T.; Jablonska, P. T. Polish J. Chem. 1982, 56, 1297.

26. Jaxa-Chamiec, A. A; Sammes, P. G.; Kennewell, P. D. J. Chem. Soc. Perkin Trans. 1 1980, 170.

27. Cass, Q. B.; Jaxa-Chamiec, A. A; Sammes, P. G. J. Chem. Soc. Chem. Commun. 1981, 248.

28. Thomas, A. Tetrahedron 1991, 47, 4905.

29. Lee, K. Bull. Korean Chem. Soc. 2011, 32, 3477.

30. Subramaniam, P.; Thamil Selvi, N. Am. J. Anal. Chem. 2013, 4, 20.

31. Walker, D.; Leib, J. Can. J. Chem. 1962, 40, 1242.

32. Kenney, W. J.; Walsh, J. A.; Davenport, D. A. J. Am. Chem. Soc. 1961, 83, 4019.

33. Signorella, S.; Rizzotto, M.; Daier, V.; Franscaroli, M. I.; Palopoli, C.; Martino, D.; Boussekou, A.; Sala, L. F. J. Chem. Soc. Dalton Trans. 1996, 1607.

34. Perez-Benito, J. F.; Arias, C. J. Phys. Chem. A 1997, 101, 4726.

35. Palopoli, C. M.; Signorella, S. R.; Sala, L. F. New J. Chem. 1997, 21, 343.

36. Hamm, R. E.; Johnson, R. L.; Perkins, R. H.; Davis, R. E. J. Am. Chem. Soc. 1958, 80, 4469. 
37. Shahid, M.; Khan, I. A.; Kabir-ud-Din. J. Chem. Soc. Dalton Trans. 1990, 3007.

38. Kabir-ud-Din.; Hartani, K.; Khan, Z. Colloids Surf. A Physicochem. Eng. Asp. 2001, 193, 1.

39. Abid, M.; Khan, Z. Trans. Met. Chem. 2003, 28, 79.

40. Gonzalez, J. C.; Daier, V.; Garcia, S.; Goodman, B. A.; Atria, A. M.; Sala, L. F. J. Chem. Soc. Dalton Trans. 2004, 15, 2288.

41. Wiberg, K. B. Oxidation in Organic Chemistry, Part A; Academic Press: New York, 1965; pp 60-184.

42. Das, A. K.; Mondal, D.; Kar, D.; Das, M. Int. J. Chem. Kinet. 2001, 33, 173.

43. Mangalam, G.; Gurumurthy, R.; Arul, R.; Karthikeyan, R. Indian J. Chem. 1995, 34B, 107.

44. Meenakshisundaram, S.; Vinothini, R. Croat. Chem. Acta. 2003, 76, 75.

45. Karunakaran, C.; Karuthapandian, S.; Suresh, S. Int. J. Chem. Kinet. 2003, 35, 1.

46. Amis, E. S. Solvent Effects on Reaction Rates and Mechanisms; Academic Press: New York, 1967, pp 42-48.

47. Nandibewoor, S. T.; Morab, V. A. J. Chem. Soc. Dalton Trans. 1995, 483.

48. Karunakaran, C.; Chidambaranathan, V. Monatsh Chem. 2000, 131, 1123.

49. Petersen, R. C.; Markgraf, J. H.; Ross, S. D. J. Am. Chem. Soc. 1961, 83, 3819.

50. Exner, O. Collect. Czech. Chem. Commun. 1964, 29, 1094.

51. Exner, O. J. Chem. Soc. Perkin Trans. 2 1993, 973.

52. Chellamani, A.; Alhaji, N. M. I.; Rajagopal, S.; Sevvel, R.; Srinivasan, C. Tetrahedron 1995, 51, 12677.

53. Chellamani, A.; Alhaji, N. M. I.; Rajagopal, S. J. Chem. Soc. Perkin Trans. 2 1997, 299.

54. Chellamani, A.; Kulanthaipandi, P.; Rajagopal, S. J. Org. Chem. 1999, 64, 2232.

55. Chellamani, A.; Harikengaram, S. J. Mol. Catal. A 2006, $247,260$.
56. Mahapatro, S. N.; Krumpolc, M.; Rocek, J. J. Am. Chem. Soc. 1980, 102, 3799.

57. Shen-Yang, T.; Li, K.-A. Talanta 1986, 33, 775.

58. Brasch, N. E.; Buckingbam, D. A.; Evans, B. A.; Clark, C. R. J. Am. Chem. Soc. 1996, 118, 7969.

59. Levitt, L. S. J. Org. Chem. 1955, 20, 1297.

60. Westheimer, F. H. Chem. Rev. 1949, 45, 419.

61. Lay, P. A.; Levina, A. Inorg. Chem. 1996, 35, 7709.

62. Pedrosa de Jesus, J. O'Brien, P. Polyhedron 1992, 11, 1687.

63. Kaiwar, S. P.; Sreedhara, A.; Raghavan, M. S. S.; Rao, C. P.; Jadhav, V.; Ganesh, K. N. Polyhedron 1996, 15, 765.

64. Thenraja, D.; Subramaniam, P.; Srinivasan, C. Tetrahedron 2002, 58, 4283.

65. Murray, R. W.; Jeyaraman, R.; Krishna Pillai, M. J. Org. Chem. 1987, 52, 746.

66. Bloodworth, A. J.; Melvin, T.; Mitchell, J. C. J. Org. Chem. 1988, 53, 1078.

67. Ganesan, T. K.; Rajagopal, S.; BoscoBharathy, J. R.; Md. Sheriff, A. I. J. Org. Chem.1998, 63, 21.

68. Watanabe, Y.; Iyanagi, T.; Oae, S. Tetrahedron Lett. 1980, $21,3685$.

69. Laleu, B.; Santarem Machado, M.; Lacour, J. Chem. Commun. 2006, 2786.

70. Crossno, S. K.; Kalbus, L. H.; Kalbus, G. E. J. Chem. Edn. 1996, 73, 175.

71. Hasan, F.; Rocek, J. Tetrahedron 1974, 30, 21.

72. Mitewa, M.; Bontchev, P. R. Coord. Chem. Rev. 1985, 61, 241.

73. Codd, R.; Dillon, C. T.; Levina, A.; Lay, P. A. Coord. Chem. Rev. 2001, 537, 216.

74. Gould, E. S. Coord. Chem. Rev. 1994, 651, 135.

75. Ghosh, M. C.; Gould, E. S. J. Am. Chem. Soc. 1993, 115, 3167.

76. Scott, S. L.; Bakac, A.; Espenson, J. H. J. Am. Chem. Soc. 1992, 114, 4205. 